\title{
Attribute Attractiveness of City, City Brand Love and Tourist Behavior: the Case of Jakarta
}

\author{
Elia Ardyan, Naili Farida \\ Public Administration, Doctoral Program, Faculty of Social and Political Science \\ Diponegoro University \\ Semarang, Indonesia \\ (Office Email:prodidap@gmail.com)
}

\begin{abstract}
This research is conducted to answer two questions research, namely (1) how the influencing attribute does table of city attractiveness on a city brand love? (2) How does the influence of city brand love on tourist behavior (visiting back and positive word of mouth? This research examines 162 tourists already several times visiting Jakarta city, Indonesia. The analysis in this study is using Structural Equation Modeling (SEM) and to process data using the AMOS version 20. The results of this research show that the whole hypothesis is accepted, among others: (1) the attractiveness of the city attribute has a positive and significant influence on the city brand love; (2) the city brand love has positive and significant influence on repeat visitation; and (3) city brand love has a positive influence and significant on word of mouth.
\end{abstract}

Keywords-Attractiveness Attribute of City; City Brand Love; Tourist Behavior; Positive Word of Mouth

\section{INTRODUCTION}

In the very tight competition and globalizing, all companies have done invasion. All companies should be able to make their own character compared to competitors. As well as selling a product, the city is also a product that should be introduced and marketed by the Government of its country. Local authorities should make proper positioning, where a city should have different strengths and perceived existence when compared with other cities. Local governments should be able to exhibit the idiosyncrasies of a city well on investors or tourists, as this will greatly affect the goal economic achievement, political or social-psychological (Kavaratzis\& Ashworth, 2005) as planned by the city government. The city Government should be able to make a variety of interesting attributes of its city. Snieska and Zykiene (2015) and De Noni, Orsi, and Zanderighi (2014) states that various attributes such as developed healthcare quality, social service quality, cultural quality, level quality, environmental safety, economic development level, and education quality are developed so that people got interested and visiting this city. The more attractive city, then the love of the city and tourists in future tourists will visit tourist destinations both on a birthday or just come to the city.

There are three research questions in this study as follows:
(1) How the influence of attribute does table of city attractiveness on a city brand love?

(2) How does the Influence of city brand love on tourist behavior (visiting back and positive word of mouth?

Zykiene and Snieska (2011) define attractiveness as perceptions about the resource that is owned by the city, the city's ability management and exploit it, and obtain the advantages compare to other cities and beliefs about the city development. In this study, we define the attribute table of city attractiveness as various attractiveness factors that are owned by a city seen from both programs which create City Government, public service, potential tourist destinations as well as the development of city in the future. Various attributes created by the City Government aims so that tourists would like to come and visit this city, either visit the travel destinations or just come to the city.

The first is the concept of brand love means the relationship between brands with consumers (Drennan et al., 2000). These relationships are not only just ordinary, but also in a long-term relationship (Fournier, 1998). Brand love is defined as the emotional attachment level a passionate consumer and content that exists on a particular brand (Barbara \& Ahuvia, 2006). Brand love is arising out of satisfaction on a brand continuously. In this study, the interesting city will be able to make the tourists like this city. The more people love a city, Then they will have a desire to come back. Tourists will also recommend to their friend, family or their contact to visit this city.

From the explanation above, we propose the following hypothesis as follows:

H1: The more interesting attribute of a city then the tourists will love

H2A: The tourists loving a city then the tourists will come back to this city

$\mathrm{H} 2 \mathrm{~b}$ : The tourists loving a city then the tourists will recommend it to other people. This table is the model of empirical research developed in this study: 


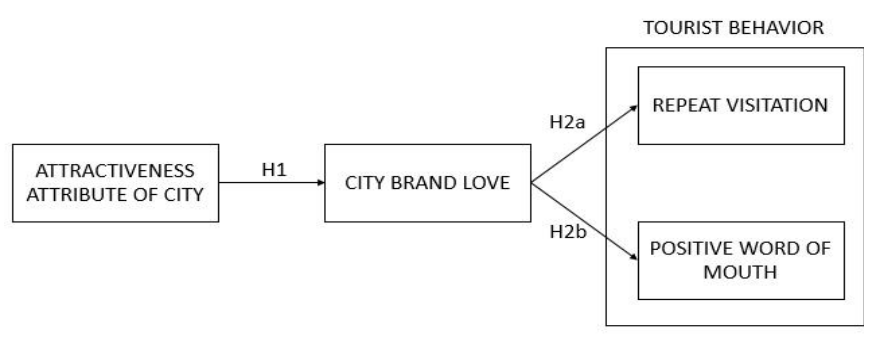

\section{TheOretical FramewOrK AND Method}

To obtain the data, a questionnaire is distributed by 300 respondents who several times have been to Jakarta. From 300 questionnaires obtained, only 162 that can be used in this study. The analysis in this study is using Structural Equation Modeling (SEM) and to process data using the AMOS version 20. The questionnaire items measurement of this study is using a scale from 1 to 7 , where 1 show strongly disagree and 7 scale shows very agree. This study uses 4 invalid constructs namely city brand attractiveness, memorable city brand experience, brand love and brand equity.

Attribute Attractiveness of the City. City brand attractiveness is the appeal of various factors that is owned by a city seen from both programs which create City Government, public service, potential tourist destinations as well as the city development in the future. The dimensions in this study adopted by Snieska and Zykiene (2015) and De Noni et al. (2001) as follows: (1) Healthcare quality, (2) Social service quality, (3) Culture quality, (4) Safety level, (5) Environmental quality, and (6) Education quality.

City brand love, City brand love is defined as the emotional attachment level passionate tourist and the happiness that exists in a certain city. The dimensions of the city brand love is adopted from Barbara and Ahuvia (2006), among other things: (1) awesome city brand, (2) love city brand, (3) pure delight city brand, (4) Passion with city brand, (5) attached with city brand. Tourist behavior, Tourist behavior is defined as a range of behaviors that are owned by tourists as the output of the previous behavior. In this study, the dimensions of the tourist behavior seen from repeat visitation (visiting tourist attractions in this city, visiting the city again with the intention of only roads, and revisits historic sites) and positive word of mouth (recommend a friend and recommend on the family). Dimensions of tourist behavior are adopted from Loureiro (2014).

\section{RESUlt AND DiscusSiON}

\section{A. The Result of Structural Model}

Goodness of fit is the suitability models that are built with the data retrieved. The indicators are throughout the model fit is already showing the value of the above required. The indicators are used, among others, CMIN/DF $(1,814)$, GFI $(0,904)$, NFI $(0,950)$, RFI $(9,34)$, IFI $(0,977)$, TLI $(0,969)$, CFI $(0,977)$, and RMSEA $(0,071)$.

Hypothesis test is used to test whether the proposed hypothesis is accepted or not. In this study the whole hypothesis is accepted. Hypothesis 1 suggests that the attractiveness of the city attribute has a positive and significant influence on this city brand love $(\mathrm{B}=0,978 ; \mathrm{p}<0.05)$. Hypothesis 2a shows that city brand love has positive and significant influence on repeat visitation $(B=0,627, p<0.05)$. Hypothesis $2 \mathrm{~b}$ shows that city brand love has positive and significant influence on word of mouth $(B=0,627 ; p<0.05)$.

The City Government should be able to take variety of venture capital so loved by tourists visiting this city. In this study show that when the City Government is very mindful of how to make the various attributes of the city (healthcare quality, social service quality, culture quality, safety level, environment quality and education quality) then the tourists will be increasingly loves the city. Tourists are starting to have a sense of love when they see the Government efforts in improving these various qualities. The various innovations will be able to improve the various services quality, programs, and activities undertaken. The more qualified and interestingly attribute is developed by the City Government, the more people are going to love the city.

This study can also be inferred that the tourists love the city then tourists will have a tendency to do a return visit in the future. Taste like tourist destinations or services conducted by the City Government will make to promote tourist on a friend, brother, or their associate. Doing so will greatly impact on the income and wealth of the city.

\section{CONCLUSION}

The City Government ability in creating various attributes of interest and an important quality to increase the tourists interesting on a city. Getting the tourist interesting in a city then the tourists will visit and recommend to their friends.

Managerial implications in this research is the City Government must innovate in bring up the various attributes who will be later create tourists interesting in the city. The long run of a love is tourists will generate positive recommendations and visits about the city to others. The City Government should also make a variety programs and activities that will encourage quality and Interestingly City attribute. For research that will come, we recommend: (1) expand the existing samples and (2) examining research model that we wake up with a way to compare two or more cities that have different positioning.

\section{REFERENCES}

[1] Barbara, A. C., \& Ahuvia, A. C. (2006). Some antecendents and outcomes of brand love. Market Letters, 17, 79-89.

[2] De Noni, I., Orsi, L., \& Zanderighi. (2014). Attributes of Milan Influencing City Brand Attractiveness. Journal of Destination Marketing \& Management, 3, 218-226.

[3] Drennan, J., Bianchi, C., Cacho-Elizondo, S., Louriero, S., Guibert, N., \& Proud, W. (2015). Examining the role of wine brand love on brand loyalty: A multi-country comparison. International Journal of Hospitality Management, 49, 47-55.

[4] Fournier, S. (1998). Consumers and Their Brands: Developing Relationship Theory in Consumer Research. Journal of Consumer Research, 24(March), 343-373. 
[5] Kavaratzis, M., \& Ashworth, G. (2005). City branding: An effective assertion of identity of a transitory marketing trick? Tijdschrift voor Economische en Sociale Geografie, 96(5), 506-514.

[6] Loureiro, S. M. C. (2014). The Role of Rural Tourism Experience Economy in Place Attachment and Behavioral Intentions. International Journal of Hospitality Management, 40, 1-9.

[7] Snieska, V., \& Zykiene, I. (2015). City attractiveness for investment: characteristics and underlying factors. Procedia-Social and Behavioral Sciences, 2123, 48-54.

[8] Zykiene, I., \& Snieska, V. (2011). Fizines infrastrukturos itika regioniniam patrauklumui. Economics and management, 16, 465-471. 